\title{
Evaluasi Kebijakan Revitalisasi Pasar Tradisional : Studi Pasar Akau Potong Lembu Kota Tanjungpinang
}

\author{
Jamhur Poti $^{1 *}$, Mahadiansar ${ }^{2}$ \\ ${ }^{1}$ Ilmu Administrasi Negara, Universitas Maritim Raja Ali Haji, Indonesia \\ ${ }^{2}$ Ilmu Administrasi Publik, Universitas Brawijaya, Indonesia
}

\begin{abstract}
Revitalizing traditional markets is a form of improving the quality of public space as a policy of the regional government in cooperation with local communities. The purpose of revitalizing traditional markets is not merely to improve the physical form of traditional markets but also to manage these traditional markets. The researcher raised a case study on the policy after revitalizing the Lembu Market, Tanjungpinang City, to what extent the policies that have been implemented before and after the market revitalization match the public's expectations, it is necessary to evaluate the programs that have been implemented. Researchers used policy evaluation techniques with a formal evaluation approach using Dunn 2018 theory. The research method used by researchers used library research, by carrying out a search of several library sources such as e-books, journals, websites, organizational reports and other good documents. print and online relevant to the topic being evaluated. The results showed that the evaluation of the revitalization program for the beef slaughter market in the city of Tanjungpinang had not found the value of cross-impact analysis and disconting on the program so that the revitalization of traditional markets was only in the form of target mapping, value clarification and mapping of barriers that had become the impact of the revitalization policy of the traditional cattle slaughter market in Tanjungpinang City. The researcher also did not find Urgensy in realizing the traditional market revitalization policy in order to change the characteristics of the market for the better.
\end{abstract}

Keywords :evaluation, revitalization, traditional market, tanjungpinang city

\begin{abstract}
Abstrak
Revitalisasi pasar tradisional merupakan bentuk perbaikan kualitas ruang publik sebagai kebijakan pemerintah daerah bekerja sama dengan masyarakat daerah. Tujuan dari revitalisasi pasar tradisional tidak semata-mata hanya pada perbaikan bentuk fisik pada pasar tradisional melainkan pada pengelolaan pasar tradisional tersebut. Peneliti mengangkat studi kasus pada kebijakan setelah di revitalisasi Pasar Potong Lembu Kota Tanjungpinang sejauh mana kebijakan yang telah di laksanakan sebelum dan sesudah revitalisasi pasar tersebut sesuai harapan publik maka perlunya evaluasi terhadap program yang telah dilaksanakan. Peneliti mengunakan teknik evaluasi kebijakan dengan pendekatan evaluasi formal mengunakan teori Dunn 2018. Metode penelitian yang peneliti gunakan studi kepustakaan (library research), dengan melakukakan penelusuran terhadap beberapa sumber-sumber pustaka seperti e-book, journal, website, laporan organisasi dan dokumen lainnya baik cetak maupun online yang relevan dengan topik yang sedang di evaluasi. Hasil penelitian menunjukan evaluasi kebijakan program revitalisasi pasar potong lembu kota tanjungpinang belum terdapat nilai analisis dampak silang dan diskonting terhadap program tersebut sehingga revitalisasi pasar tradisional hanya bersifat pemetaan sasaran, klarifikasi nilai serta pemetaan hambatan yang telah menjadi dampak kebijakan revitalisasi pasar tradisional potong lembu kota tanjungpinang. Peneliti juga tidak menemukan Urgensy dalam merealisasikan kebijakan revitalisasi pasar tradisional tersebut dalam rangka mengubah karakteristik pasar menjadi lebih baik.
\end{abstract}

Kata kunci: evaluasi, revitalisasi, pasar tradisional, kota tanjungpinang

*jamhur_poti@umrah.ac.id

DOI: https://doi.org/10.26618/kjap.v6i3.4165 


\section{PENDAHULUAN}

Revitalisasi pasar tradisional merupakan salah satu cara dalam menciptakan ruang publik yang mengedepankan kenyamanan dan juga menjadi salah satu ancaman yang berdampak buruk apabila revitalisasi pasar tradisional tidak direncanakan dengan baik. Pasar tradisional pada saat ini menjadi sangat penting untuk di perhatikan karena masyarakat diberbagai kalangan manapun mudah untuk mengaksesnya. Revitalisasi pasar tradisional belum adanya secara menyeluruh di indonesia sehingga pasar tradisional minim akan mendorong perekonomian masyarakat menengah kebawah. Revitalisasi yang di maksud dalam rangka menghidupkan kembali pembangunan serta pengembangan peran dan fungsi pasar tradisional agar bisa berdaya saing dengan pasar modern demi mendukung kenyamanan aktivitas perbelanjaan oleh masyarakat yang bertujuan terciptanya pasar tradisional yang kondusif. Selain itu revitalisasi pasar tradisional juga bisa meningkatkan kesejateraan para pedagang yang berjual dalam pendapatan omzet, mendukung kelancaran logistik distribusi baik ekspor maupun impor sehingga terjadinya penguatan pasar dalam negeri.

Tabel 1.

Alokasi Anggaran Target Revitalisasi Pasar Tradisional Berdasarkan Tipe Klasifikasi pada Tahun 2019

\begin{tabular}{|c|c|c|}
\hline No. & Jenis Pasar Tradisional & Total Anggaran \\
\hline 1 & Kategori Tipe A & Rp. 11,5 Miliar \\
\hline 2 & Kategori Tipe B & Rp. 7,7 Miliar \\
\hline 3 & Kategori Tipe C & Rp. 5,8 Miliar \\
\hline 4 & Kategori Tipe D & Rp. 3,6 Miliar \\
\hline 5 & Kategori Tipe E & Rp. 1,1 Triliun \\
\hline
\end{tabular}

\section{Sumber : Kementerian Perdagangan, 2019}

Berdasarkan tabel diatas data dari kementerian perdagangan tahun 2019 menunjukan bahwa kebijakan pada target revitalisasi pasar tradisional sangat diperhatikan dengan anggaran cukup besar oleh pemerintah pusat sesuai dengan klasifikasinya pada tahun 2019. Namun salah satu keberhasilan sebuah pasar tradisional yaitu pasar agung dan pasar poh gading yang ada di denpasar, diberikannya sebuah pelatihan manajemen yang baik serta pendampingan langsung sehingga kedua pasar tersebut memiliki lisensi atau sertifikasi Standart Nasional Indonesia (SNI) oleh Kementerian Perdagangan Republik Indonesia, alasannya keberhasilan kedua pasar tersebut adalah program pemerintah kota denpasar merintis sekolah pasar dengan bertujuan mengedukasi para pedangang pasar 
terhadap etika publik sehingga terwujudnya pasar tradisional yang ramah dan dapat dipercaya.

Pada tahun 2020, revitalisasi pasar tradisional yang difokuskan oleh pemerintah pusat melalui kementerian PUPR RI yaitu sebanyak empat pasar rakyat yaitu Pasar Pariaman di Kota Pariaman, Sumatra Barat kemudian Pasar Kaliwungu di Kabupaten Kendal, Jawa Timur dan Pasar Klewer, Jawa Tengah dan Pasar Sukati, Bali.

Konsep revitalisasi pasar yang dilaksanakan oleh pemerintah pusat yaitu disesuaikan dengan keselarasan lingkungan yang mempertahankan nilai-nilai kearifan lokal yang berpegang pada konsep ekonomi kerakyatan, selain itu kementerian perdagangan melalui kebijakannya pada tahun ini merevitalisasi sebanyak 1037 Pasar Rakyat yang ada di Indonesia karena hasil revitalisasi pasar pada tahun sebelumnya meningkatnya omset sebesar $20 \%$ setelah direvitalisasi pasar tradisional tersebut.

Sedangkan kebijakan daerah melalui perannya di masing -masing daerah akan revitalisasi pasar tradisional memegang konsep revitalisasi untuk sektor pangan berkelanjutan dengan menambahkan UMKM semakin meningkat. Tidak terlepas dari revitalisasi pasar trasional tersebut, faktor - faktor penghambat dalam pengembangan revitalisasi adalah kurangnya kerjasama yang baik antara pihak pedagang, artinya kepercayaan pihak pasar tradisional belum di pandang besar oleh investor yang ingin menanamkan modalnya. kemudian pemerintah maupun swasta dalam partisipasi proses revitalisasi pasar tradisional yang di anggap aturan yang ribet dan terjadi sengketa lahan di lokasi pasar tradisional tersebut.

Selain itu juga lemahnya pendekatan politik para pemilik pasar tradisional saat proses revitalisasi pasar tradisional, faktanya banyak pemerintah daerah tidak melakukan pemerataan di wilayah yang seharusnya wajib di revitalisasi sehingga pedangan pasar tradisional berprasangka demi kepentingan politik. Dibalik itu semua, ada juga faktor keberhasilan revitalisasi pasar tradisional yaitu seperti pemberdayaan sumber manusia yang lebih baik pasca revitalisasi melalui pembinaan pasar tradisional dan Secara ekonomis pendapatan penjual para pedagang sebelum dan sesudah program revitalisasi pasar memiliki dampak yang baik secara signifikan (Azizah, 2016).

Dinas Perdagangan dan Perindustrian melaksanakan revitalisasi pasar tradisional potong lembu yang dimana pasar tersebut merupakan salah satu pasar yang direvitalisasi yang telah selesai dan digunakan langsung oleh pedagang yang berjualan seperti biasanya, akan tetapi dampak hasil dari kebijakan revitalisasi 
perlu dilakukannya evaluasi kebijakan.

Pada tahun 2019 anggota Dewan Perwakilan Rakyat (DPRD) Kota Tanjungpinang melaksanakan reses ke BUMD Tanjungpinang untuk memprioritaskan pembangunan prasarana pasarAkau Potong Lembu Tanjungpinang.

Dari hasil reses tersebut dikutip melalui (sijoritoday.com) menyatakan bahwa "rencana perbaikan pasar akau potong lembu akan ditata rapi sampai 90\%, sehingga dari perbaikan pasar inpres maka dapat meningkatkan PAD Kota Tanjungpinang. Tujuan penelitian ini untuk mengungkapkan sejauhmana Evaluasi kebijakan yang diperlukan untuk melihat kesenjangan antara harapan dan kenyataan yang ada setelah pasca revitalisasi pasar potong lembu Kota Tanjungpinang.

Dampak yang akan terjadi kebijakan setelah dilakukan revitalisasi pasar tradisional bukan hanya memberikan isentif kepada para pedagang pasar tradisional, melainkan berdampak terhadap lingkungan masyarakat pada umumnya serta pemerintah hingga swasta di beberapa daerah. dampak yang akan dirasakan di antaranya :

1. Pedagang secara umum sangat terbantu bertambahnya pendapatan adanya pasca revitalisasi pasar tradisional (Stutiari \& Arka, 2019). seperti contoh dari manajemen keuangan yang sudah tersistem dengan baik melalui teknologi yang di atur dalam pengelolaannya;

2. Pembeli dalam hal ini masyarakat akan merasakan nyaman dalam transaksi belanja, mulai dari kebersihan maupun pelayanan yang baik serta pembaharuan fasilitas setelah ada revitalisasi (Darmawan et al., 2018), Seperti contoh masyarakat akan lebih percaya akan pelayanan dengan dibuktikan dengan biil atau nota pembelanjaan yang sudah tersistem sesuai harga pasar pada umumnya;

3. Pemerintah juga berhasil dalam memberikan tata ruang publik berupa pembangunan yang baik serta peningkatan pendapatan asli daerah (Prastyawan \& Isbandono, 2018), Seperti contoh wilayah yang strategis setelah direvitalisasi dan dilengkapi sarana pendukung sehingga kondisi pasar tradisional tersebut selalu di padati oleh pengunjung pasar;

4. Pihak swasta juga akan berani melakukan investasi ke pasar tradisional dengan tujuan peningkatan daya beli terhadap pasar tradisional yang telah di revitalisasi (Budianto, 2018). Meskipun investasi di indentikan dengan hal yang bersifat modern. Pasar tradional sangat berpotensi untuk mendapatkan investasi dari kalangan dengan 
mengikuti budaya sebuah pasar tradisional.

Banyak pasar tradisional berhasil melakukan revitalisasi dengan sala satunya cara pengelola pasar tradisional denpasar serta peran pemerintah mampu menginterasikan pasar tradisional dari sektor budaya, pariwisata dan dilingkungan wilayah perkotaan dengan baik dengan cara memberikan edukasi pada pedagang yang sebelumnya belum mempunyai wawasan dalam pengelolaan pasar tradisional yang baik (Rosmayanti, 2018). Saat ini pemerintah pusat melakukan target revitalisasi pasar tradisional dengan cara menunkan klasifikasi pasar berdasarkan tipe demi terwujudnya pemerataan revitalisasi pasar ke masing-masing daerah. klasifikasi tipe pasar tradisional dengan melihat tergantung kondisi pasar tradisional yang akan direvitalisasi. seperti ukuran dan jumlah kios, luas pasar hingga jumlah pedagang yang ada di dalam pasar tentunya akan di kaji oleh pemerintah pusat maupun pemerintah daerah (Reily, 2019).

Faktor sangat bergantung pada tingkat sumber daya relatif yang dimiliki oleh suatu perusahaan atau yang biasa disebut dengan comparative adventage (Sitorus, 2013). Dua faktor utama ini yang menjadi faktor penentu dalam meningkatkan daya saing. Lebih lanjut Porter (2008) menjelaskan mengenai Lima
Kekuatan Strategi Pembentuk Persaingan Industri dimana lima faktor yang menentukan kekuatan persaingan dalam suatu industry adalah; (1) ancaman dari produk pengganti, (2) ancaman pesaing lainnya, (3) ancaman yang berasal dari pendatang baru, (4) daya tawar pemasuk, serta (5) daya tawar yang dimiliki oleh konsumen.

Evaluasi tidak hanya menghasilkan kesimpulan mengenai seberapa jauh masalah yang telah terselesaikan, tetapi juga menyumbang pada klarifikasi dan kritik terhadap nilai-nilai yang mendasari kebijakan, membantu dalam penyesuaian dan perumusan kembali masalah. Sebuah kebijakan publik tidak bisa dilepas begitu saja. Kebijakan harus diawasi dan salah satu mekanisme pengawasan tersebut disebut "evaluasi kebijakan”. Efektivitas dapat diartikan sebagai suatu usaha untuk mencapai hasil yang maksimal dengan memanfaatkan sumberdaya yang ada. Evaluasi ditujukan untuk menilai sajauh mana keefektifan kebijakan publik guna dipertanggungjawabkan kepada konstituennya (Yudiatmaja, 2016).

Tresiana \& Duadji (2020) dalam bukunya mendefinisikian evaluasi kebijakan meliputi kegiatan yang menyangkut estimasi atau penilaian kebijakan yang mencakup substansi, implementasi dan dampak. Kemudian evaluasi kebijakan menurut (Haedar, 
2015) mendefinisikan bahwasanya evaluasi kebijakan sebagai upaya "pemeriksaan yang obyektif, sistematis, empiris dari dampak kebijakan yang sedang berlangsung dan program publik terhadap target dalam hal mencapai tujuan yang ingin di raihnya. Akan tetapi menekankan Syamsuddin (2017) evaluasi kebijakan hadir karena pemerintah daerah dalam upaya melaksanakan implementasi kebijakan baik secara regulasi maupun aturan dengan tidak selalu menghasilkan perubahan kebijakan besar. Sementara konsep evaluasi menyarankan 'umpan balik tersirat merupakan bagian yang melekat dari siklus kebijakan, dalam banyak studi kasus mungkin tidak bisa di operasionalkan ataupun akan dapat mengakibatkan hanya perubahan tambahan pada keberadaan evaluasi kebijakan tersebut.

Dunn (2000) evaluasi berkenaan dengan produksi informasi mengenai nilai atau manfaat hasil kebijakan yang memberi informasi yang valid dan dapat dipercaya mengenai ‘kinerja kebijakan'. Kinerja yang dimaksud akan berpengaruh pada implementor dalam melaksanakan sebuah program maupun aktifitas untuk mencapai kepuasan sebagai bentuk kepuasan etos kerja (Yudithia \& Mahadiansar, 2019)

Kedua, evaluasi memberi sumbangan pada klarifikasi dan kritik terhadap nilainilai yang mendasari pemilihan tujuan dan target. Ketiga evaluasi memberi sumbangan pada aplikasi metode dalam sebuah analisis kebijakan lainnya, termasuk 'perumusan masalah' dan 'rekomendasi'. Kemudian Muhiddin (2017) berdasarkan hasil penelitiannya bahwa valuasi kebijakan juga bisa diterjemahkan kedalam terhadap aturan maupun regulasi dalam mempersiapkan evaluasi yang diyakini memperbaiki implementasi yang telah di buat pemangku kepentingan.

\section{METODE PENELITIAN}

Metode penelitian yang peneliti gunakan studi kepustakaan (library research), dengan melakukakan penelusuran terhadap beberapa sumbersumber pustaka seperti e-book, journal, website, laporan organisasi dan dokumen lainnya baik cetak maupun online yang relevan dengan topik yang sedang di evaluasi pada penelitian terhadap evaluasi kebijakan pemerintah daerah revitalisasi pasar tradisional potong lembu di Kota Tanjungpinang.

Studi kepustakaan merupakan serangkaian aktivitas kegiatan yang berkenaan dengan metode pengumpulan data pustaka, membaca, dan mencatat serta mengelolah bahan penelitian (Zed, 2014). Selain itu pendekatan kualitatif digunakan untuk memperoeh gambaran diskriptif yang lebih luas mengenai fenomena yang 
diamati (Moleong, 2012). Karena pendekatan kualitatif dipandang mampu menggali pemaknaan terhadap fenomena secara lebih mendalam (Creswell, 2014). Hal ini bertujuan agar fenomena yang di teliti bisa menjawab dari topik penelitian yang ada agar menghasilkan penelitian yang relevan dengan kondisi pasca revitalisasi Pasar Tradisional.

Peneliti dalam menguji keabsahan penelitian mengunakan teori dari Denzin (1978) yang menjelaskan adanya triangulasi dalam menguji keabsahan data. triangulasi menjadi sangat penting dalam penelitian kualitatif. Lanjut triangulasi dapat meningkatkan kedalaman pemahaman peneliti baik mengenai fenomena yang diteliti maupun konteks di mana fenomena itu muncul, baik pemahaman yang mendalam (deep understanding) atas fenomena yang diteliti merupakan nilai yang harus diperjuangkan oleh setiap peneliti kualitatif. Sebab, penelitian kualitatif lahir untuk menangkap arti (meaning) atau memahami gejala, peristiwa, fakta, kejadian, realitas atau masalah tertentu.

\section{HASIL DAN PEMBAHASAN}

\section{Revitalisasi Pasar Tradisional Demi}

\section{Persaingan Pasar Modern}

Pasar Potong Lembu yang dikelola PT Tanjungpinang Makmur Bersama yang
Badan Usaha Milik Daerah (BUMD) Kota Tanjungpinang ini direvitalisasi sejak 17 Juni hingga 15 Desember 2019 lalu. Revitalisasi ini menghabiskan dana sekitar Rp2,7 miliar yang diperoleh dari Dana Alokasi Khusus (DAK) dari Kementerian Perdagangan Republik Indonesia dan dana pendamping sebesar Rp95 juta. Dua bangunan pasar Potong Lembu itu memiliki 96 unit kios dan 72 lapak atau meja untuk berjualan ikan dan sayuran. Pasca revitalisasi pasar potong lembu Tanjungpinang pada saat ini hasil yang telah dicapai belum maksimal dikarenakan pasar tersebut bukan merupakan pasar utama yang dimana letak strategis pasar tersebut tidak di pusat keramaian.

Hal ini menjadi tantangan utama sebagai bahan evaluasi pemerintah daerah dalam mempromosi pasar tradisional potong lembu agar dapat dinikmati oleh masyarakat yang berkunjung ke pasar tersebut. Pemerintah kota tanjungpinang harus melakukan upaya startegis dimana wilayah kota tanjungpinang yang merupakan daerah di provinsi kepulauan riau yang memiliki posisi dengan kawasan tetangga di beberapa Negara seperti Malaysia dan singapura yang nantinya para wisata asing mancanegara akan melihat hasil revitalisasi pasar tersebut dalam kunjungannya.

Terlebih pasar tradisional potong lembu kotera tanjungpinang merupakan 
pasar yang sering dikunjungi para wisata kuliner dengan melestarikan budaya dan karakteristik pasar sebagai pasar negeri rumpun melayu yang mana ini menjadi penting di kelola dan diawasi setalah pasca revitalisasi pasar. Pencapaian kebijakan pemerintah daerah terhadap revitalisasi pasar tersebut sesuai dengan harapan pengelola pasar tradisional potong lembu kota tanjungpinang.

Pencapaian yang dimaksud adalah pasar yang higienis, bersih dan nyaman serta penjual juga bisa sejahtera dalam upaya peningkatan perekonomian pada saat ini meskipun hasil dari analisis penulis belum berdampak signifikan, akan tetapi pasar tradisional bukan berbicara tentang fisik daja melainkan manajemen SDM dan SDA harus di tata dengan baik.

\section{Analisis Dampak Evaluasi Kebijakan Revitalisasi Pasar Tradisional}

\section{Efektivitas}

Efektivitas berkenaan mengenai sesuatu yang bersifat alternative mencapai hasil yang diharapkan, atau mencapai tujuan dari diadakannya tindakan. Efektivitas berhubungan dengan rasionalitas teknis, yang diukur melalui unit produk atau layanan serta nilai moneternya Dunn (2003). Selanjutnya Budiani (2017) untuk mengukur efektivitas disuatu program dapat dilakukan dengan dilihat dari empat faktor diantaranya, ketepatan sasaran program, sosialisasi program, pencapaian tujuan program, Pemantuan program.

Dari hasil temuan peneliti efektivitas pada revitalisasi pasar tradisional akau potong lembu tanjungpinang adanya keterlambatan penyelesaian program. Didalam temuan BPK Kepulauan Riau kurang optimalnya dalam mengendalikan pelaksanaan kegiatan antara Pejabat Pembuat Komitmen (PPK) serta Pejabat Pelaksana Teknis Kegiatan (PPTK) temuan ini didasari karena lemahnya Pemantauan Program. sehingga temuan yang terjadi oleh BPK Kepulauan Riau.

Adanya kekurangan volume pekerjaan revitalisasi pasar Sebesar Rp 106.263.471,53. sedangkan denda keterlambatan penyelesaian pekerjaan yang belum dipungut sebesar Rp 333.964.057,10 pada delapan paket pekerjaan di tiga OPD Kota Tanjungpinang. Kurang optimalnya dalam pengendalian program revitalisasi pasar ini hamper sama dengan hasil penelitian terdahulu oleh Khotimah et al (2017) menyatakan kurangnya efektivitas revitalisasi pasar tradisional diakibatkan oleh kurang maksimalnya komponen fisik, sosial ekonomi dan pengelolaan, adanya komponen sosial yang dinilai kurang efektif dalam revitalisasi pasar tradisional. 


\section{Efisiensi}

Efisiensi merupakan tingkat kehematan dalam menggunakan sumber daya yang ada dalam rangka menggunakan sumber daya yang ada untuk mecapai tujuan yang diinginkan (Muchdoro, 1997). Sumber daya yang ada pada revitalisasi pasar tradisional menyeimbangkan potensi yang ada dari rencana hingga hasil yang ada.

Sedangkan menurut Mulyadi (1998) efisiensi adalah pengendalian biaya atau pengorbanan sumber daya ekonomi yang diukur dalam satuan uang yang telah terjadi untuk mencapai sebuah tujuan yang telah ditetapkan. Hubungannya program revitalisasi pasar tradisional ini bila output yang dihasilkan dengan biaya yang rendah. Suatu tindakan yang dikatakan efektif apabila mencapai hasil maksimal dengan usaha tertentu yang diberikan.

Revitalisasi pasar tradisional akau potong lembu tanjungpinang yang di kelola langsung oleh BUMD Kota Tanjungpinang. Direvitalisasi pada 17 Juni hingga 15 Desember 2019 dengan anggaran mencapai $\mathrm{Rp} 2,7$ miliar yang bersumber dari Dana Alokasi Khusus (DAK) Kementerian Perdagangan Republik Indonesia dan dana pendamping sebesar Rp95 juta.

Bangunan pasar Potong Lembu memiliki 96 unit kios dan 72 lapak atau meja untuk berjualan ikan dan sayuran. Dari alokasi dana yang diberikan pemerintah output yang diberikan untuk usaha pedagang hanya bentuk bangunan namun tidak ada upaya bagaimana pengelolaan yang diberikan untuk peningkatan dari tujuan pemerintah untuk meningkatkan PAD kota Tanjungpinang.

Hal ini sangat memprihatinkan dibuktikan adanya keluhan masyarakat dengan pasca pembangunan yang telah selesai tidak memberikan hasil maksimal, seperti tampak pondasi bangunan Kios yang tidak diperbaiki masih terlihat seperti keadaan yang dahulunya. Seharusnya pemerintah bisa mengendalikan permasalahan ini dengan perencanaan bangunan dengan melibatkan masyarakat. Memiliki kesamaan dengan penelitian yang dilakukan oleh (Irvin \& Stansbury, 2004) yang mengatakan bahwa keterlibatan (partisipasi) masyarakat akan menghasilkan keputusan yang lebih baik dan lebih efisien bagi warga negara.

\section{Kecukupan}

Selanjutnya menurut Winarno (2002) kecukupan dalam kebijakan publik dapat dikatakan tujuan yang telah dicapai sudah dirasakan mencukupi dalam berbagai hal. Kecukupan (adequacy) berkenaan dengan seberapa jauh suatu 18 tingkat efektivitas memuaskan kebutuhan, nilai, atau kesempatan yang menumbuhkan adanya 
masalah Kecukupan masih berhubungan dengan efektivitas dengan mengukur atau memprediksi seberapa jauh alternatif yang ada dapat memuaskan kebutuhan.

Nilai atau kesempatan dalam menyelesaikan masalah yang terjadi. Kecukupan dalam kebijakan publik dapat dikatakan tujuan yang telah dicapai sudah dirasakan mencukupi dalam berbagai hal. Kemudian Dunn mengemukakan bahwa kecukupan (adequacy) berkenaan dengan seberapa jauh suatu tingkat efektivitas memuaskan kebutuhan, nilai, atau kesempatan yang menumbuhkan adanya masalah. Namun Dunn (2003) dari pengertian diatas dapat disimpulkan bahwa kecukupan masih berhubungan dengan efektivitas dengan mengukur atau memprediksi seberapa jauh alternatif yang ada dapat memuaskan kebutuhan, nilai atau kesempatan dalam menyelesaikan masalah yang terjadi.

Penelitian yang dilakukan oleh Nilda et al (2014) menyatakan pada program revitalisasi adanya peningkatan yang terjadi dari segi kenyamanan dan keamanan pasar itu didasari adanya peningkatan kualitas fasilitas seperti toilet, mushola, halaman pasar, pujasera, dan kantor pengelola dan dilengkapi dengan adanya keamanan pasar.

Berbedanya dengan hasil penelitian yang dilakukan pada revitalisasi pasar potong lembu tanjungpinang hanya penambahan kios serta meja untuk pedagang saja yang dilakukan dalam hal ini kecukupan belum sepenuhnya memuaskan kebutuhan untuk masyarakat.

\section{Pemerataan}

Pemerataan dalam kebijakan publik dapat dikatakan mempunyai arti dengan keadilan yang diberikan dan diperoleh sasaran kebijakan publik. Dunn (2003) menyatakan bahwa kriteria kesamaan (equity) erat berhubungan dengan rasionalitas legal dan sosial dan menunjuk pada distribusi akibat dan usaha antara kelompok-kelompok yang berbeda dalam masyarakat. Kebijakan yang berorientasi pada perataan adalah kebijakan yang akibatnya atau usaha secara adil didistribusikan.

Suatu program tertentu mungkin dapat efektif, efisien, dan mencukupi apabila biaya manfaat merata. Kunci dari perataan yaitu keadilan atau kewajaran. Revitalisasi pasar tradisional yang dilakukan oleh pemerintah kota Tanjungpinang dan pasar potong lembu terkesan tidak berpihak pada kepentingan pedagang. Sebagai indikasi keterlibatan pedagang sebagai bagian dari pemangku kepentingan adalah salah atau sekadar memenuhi aturan tata pemerintahan daerah yang baik.

Pendekatan manajemen publik baru yang menempatkan nilai-nilai pasar 
sebagai pijakan dalam mempercepat pertumbuhan ekonomi menyebabkan ketidakadilan sosial yang lebih besar karena kelompok-kelompok kapitalis semakin diuntungkan. Pendapat ini diperkuat oleh Denhardt \& Denhardt (2015) mengatakan bahwa kepentingan publik adalah hasil dialog dan keterlibatan publik dalam pencarian nilai dan kepentingan bersama, bukan sebagai agregasi kepentingan pribadi. Diperlukan niat baik untuk melibatkan masyarakat dalam administrasi untuk pencapaian tujuan secara efektif dan efisien dan demi nilai-nilai demokrasi.

\section{Responsivitas}

Responsivitas dalam kebijakan publik dapat diartikan sebagai respon dari suatu aktivitas. yang berarti tanggapan sasaran kebijakan publik atas penerapan suatu kebijakan. Menurut Dunn (2003) menyatakan bahwa responsivitas berkenaan dengan seberapa jauh suatu kebijakan dapat memuaskan kebutuhan, preferensi, atau nilai kelompok-kelompok masyarakat tertentu.

Suatu keberhasilan kebijakan dapat dilihat melalui tanggapan masyarakat yang menanggapi pelaksanaan setelah terlebih dahulu memprediksi pengaruh yang akan terjadi jika suatu kebijakan akan dilaksanakan, juga tanggapan masyarakat setelah dampak kebijakan sudah mulai dapat dirasakan dalam bentuk yang positif berupa dukungan ataupun wujud yang negatif berupa penolakan. Kriteria responsivitas adalah penting karena analisis yang dapat memuaskan semua kriteria lainnya (efektivitas, efisiensi, kecukupan, kesamaan) masih gagal jika belum menanggapi kebutuhan aktual dari kelompok yang semestinya diuntungkan dari adanya suatu kebijakan.

Dari sumber informasi yang didapatkan peneliti menyatakan bahwa responsivitas masyarakat tidak terlalu puas terhadap program revitalisasi tersebut. Harapan pemerintah kota tanjungpinang dengan dilakukan nya revitalisasi ini diharapkan mampu menarik minat masyarakat untuk berbelanja sehingga dapat meningkatkan pendapatan pedagang (lihat pada laman website batam.tribunnews.com).

Sependapat dengan penelitian Aliyah et al (2014) yang telah mengetahui dan meyakini bahwa pasar tradisional dapat memberikan kontribusi dalam pengembangan ekonomi masyarakat, maka mereka akan lebih termotivasi dan bersemangat untuk mendukung upaya revitalisasi pasar.

\section{Ketepatan}

Dalam proses ini keberhasilan suatu kebijakan dapat dilihat dari tujuan kebijakan yang benar-benar tercapai 
berguna dan bernilai pada kelompok sasaran, mempunyai dampak perubahan sesuai dengan misi kebijakan tersebut. Menurut Pangestu (2004) revitalisasi pasar berarti perubahan pasar secara fisik dan pengelolaanya secara modern yang ditujukan untuk memacu pertumbuhan pasar dengan upaya untuk menyelaraskan pasar tradisional dengan lingkunganya, dan sesuai dengan tuntutan kebutuhan masyarakat.

Mengacu pada pengertian di atas, revitalisasi pasar tradisional berarti upaya mensinergiskan sumberdaya yang ada di pasar tradisional secara komprehensif dan terintegrasi sehingga dapat meningkatkan daya saing pasar tradisional dengan tetap mempertahankan kekhasan dan keunggulan yang dimiliki pasar tersebut. Aliyah (2017) juga menyampaikan bahwa pasar tradisional dalam hal pelayanan konsumen mengandalkan modal utamanya pada kenyamanan, kebersihan, dan keamanan lingkungan. Dengan kata lain, tanpa elemen tersebut, pasar tradisional tidak akan terevitalisasi dengan baik. Dari hasil analisis peneliti melalui data sekunder pada indikator ketepatan, tujuan dari revitalisasi pasar potong lembu ini belum sepenuhnya mencapai hasil yang diinginkan masyarakat.

\section{Dampak Revitalisasi Pada Moral Sosial dan Ekonomi Kerakyatan}

Perlunya dorongan daya saing serta perhatian yang lebih terhadap revitalisasi pasar tradisional potong lembu kota tanjungpinang dikarenakan pasar tradisional merupakan salah satu penggerak ekonomi kerakyatan yang harga terjangkau dan bisa melakukan transaksi tawar menawar harga sebuah produk diinginkan yang tidak di jumpai pada pasar modern.

Problematika pasar tradisional potong lembu saat ini pada kualitas pengelolaan manajemen yang sangat lebih baik dari pada pasar tradisional yang pada umumnya pedangan memang belum menguasai teknik manajemen dan tata kelola pasar yang baik dan benar. Hal ini menjadi ketertarikan masyarakat akan pasar tradisional kurang adanya daya tarik untuk diminati oleh masyarakat yang ingin berbelanja, terlebih kaum milenial sangat identik terhadap perkembangan zaman yang bersifat modern.

Paradigma pada masyarakat tanjungpinang yang terjadi saat ini dimasyarakat akan pasar tradisional potong lembu tanjungpinang lebih identik terhadap kebersihan serta fasilitas yang dianggap tidak memenuhi kriteria pasar, apalagi pasar tradisional secara umum dilatarbelakangi oleh penjual prilaku yang kurang baik dari segi pelayanan sehingga 
ketidaknyaman pembeli ketika belanja memiliki keraguan dan timbul rasa ketidak nyamanan, contohnya ada oknum kecurangan dalam melakukan perhitungan sebuah barang belanja yang di anggap mahal oleh pembeli dan tidak mengikuti manajemen pasar sesuai dengan kisaran harga yang telah di tentukan oleh pasar modern.

Dengan di dorongnya revitalisasi pasar tradisional, bukan hanya mengrevitalisasikan dalam bentuk infrastuktur melainkan perlunya aturan maupun sistem pasar yang terintegrasi dengan tidak menghilangkan kekhas tradisional sebuah pasar tradisional potong lembu.

\section{Analisis Evaluasi Kebijakan Pendekatan Evaluasi Formal}

Hasil dari kebijakan revitalisasi pasar tradisional responsivitas dan ketepatan dalam memilih pasar tradisional di kota tanjungpinang memang tidak menuai kritik karena belum terdapat nilai analisis dampak silang, analisis dampak silang ini yang dimaksud adalah terhadap lingkungan belum berpengaruh signifikan, menurut perhimpunan pasar tradisional potong lembu, fahmi menerangkan pasar tersebut dikarenakan memang belum memiliki rencana startegis yang diperuntukan setelah revitalisasi pasar tradisional potong lembu tanjung pinang.
Kemudian diskonting terhadap program tersebut belum ada laporan yang terperinci dari Dinas Industri dan Perdagangan Kota Tanjungpinang dengan alasan pemerintah kota tanjungpinang hanya merevitalisasi kontruksi pasar dan manajemen sehingga revitalisasi pasar tradisional hanya bersifat pemetaan sasaran sesuai dengan kebutuhan nasional yang menjadi program prioritas pemerintah pusat.

Klarifikasi nilai dalam evaluasi kebijakan informal hanya bersifat administratif dalam mendukung faktor terlaksananya revitalisasi sehingga belum ada informasi publik terhadap klasifikasi nilai target dan sasaran pemerintah dalam melaksanakn progma tersebut serta pemetaan hambatan yang telah menjadi dampak kebijakan revitalisasi pasar tradisional potong lembu kota tanjungpinang.

Pemetaan hambatan yang dimaksud adalah pasar tradisional potong lembu belum memiliki urgensi untuk di revitalisasi dikarenakan banyak pihak swasta pada saat revitalisasi yang seharusnya dilaksanakan sebagai program pemerintah daerah kota tanjungpinang kini hadir dengan keterlibatan pihak swasta yang ikut andil dalam revitalisasi pasar tradisional tersebut. 


\section{KESIMPULAN}

Revitalisasi pasar tradisional bertujuan untuk menjaga kultur, tradisi dan budaya pasar tradisional yang menjadi warisan terdahulu sebagai bentuk icon indonesia yang melekat kepada kebiasaan masyarakat yang nantinya akan menjadi potret dunia tentang pasar tradisional di indonesia. Masa depan pasar tradisional mampu berdaya saing dengan pasar modern sesuai kebutuhan perkembangan zaman dari waktu ke waktu dengan tidak menghilangkan esensi pasar tradisional seperti seharusnya.

Masa depan revitalisasi akan tergantung perhatian pemerintah terhadap revitalisasi pasar, sebagaimana di ketahui pengelolaan revitalisasi cukup besar anggarannya jika tidak ada badan pengawas untuk mengawasi proses revitalisasi demi menghindari potensi penyalagunaan anggaran revitalisasi.

Revitalisasi pasar tradisional potong lembu tanjungpinang bisa berkembang karena sesuai dengan kebutuhan dari waktu ke waktu. Akan tetapi bisa juga revitalisasi pasar tradisional ini memberikan dampak negatif buruk ketika banyaknya kepentingan. Pada akhirnya program revitalisasi pasar tradisional belum cukup memenuhi kebutuhan pasar tradisional sesuai dengan standartnya dibandingkan beberapa pasar yang ada di wilayah kota tanjungpinang.

Kemudian saran dari peneliti dari pihak pemerintah kota tanjungpinang harus melakukan evaluasi terhadap program tersebut secara mendalam agar dikaji secara komperenship dan membentuk satuan tugas revitalisasi pasar tradisional secara independent yang bertujuan mengawasi proses perencaraan, pelaksanaan serta evaluasi kebijakan revitalisasi pasar agar tepat sasaran. Kemudian melibatkan para pedagang yang hendak direvitalisasi dan pengelola pasar agar keterbukaan informasi dalam revitalisasi pasar tradisional yang baik kedepannya.

\section{UCAPAN TERIMAKASIH}

Terima Kasih kami ucapkan kepada para Fakultas Ilmu Sosial dan Ilmu Politik Universitas Maritim Raja Ali Haji telah memberikan berupa program isentif publikasi karya ilmiah tahun anggaran 2019-2020. Tak lupa terima kasih kami untuk tim editor dan reviewer KOLABORASI : Jurnal Administrasi Publik universitas muhammadiyah makassar yang telah bekerja dengan menerbitkan tulisan ini dengan sempurna serta pihak-pihak yang lainnya terlibat. 


\section{DAFTAR PUSTAKA}

Aliyah, I. (2017). Pemahaman konseptual pasar tradisional di perkotaan. Cakra Wisata, 18(2), 1-16.

Aliyah, I., Setioko, B., \& Pradoto, W. (2014). Traditional market revitalization as an urban catalyst in the City of Surakarta. 3rd International Conference on Engineering \& Technology Development, 180-188.

Azizah, S. N. (2016). Analisis dampak program revitalisasi pasar tradisional di pasar tumenggungan terhadap pendapatan pedagang dan evaluasi manajemen tata kelola pedagang pasar tumenggungan pasca program revitalisasi menurut persepsi pedagang. FokBis :Media Pengkajian Manajemen Dan Akuntansi, 15(02), 22-36.

Budiani, N. W. (2017). Efektifivitas program penganggulangan engangguran Karang Taruna "Eka Taruna Bhakti" Desa Sumerta kelod Kecamatan Denpasar Tmur Kota Denpasar. Jurnal Ekonomi Dan Sosial (INPUT), 2(1), 49-57.

Budianto, A. (2018). Pertama di Bandung, Galeri investasi hadir di pasar tradisional. Sindonews.Com. https://ekbis.sindonews.com/read/130 2210/32/pertama-di-bandung-galeriinvestasi-hadir-di-pasar-tradisional1525170386/

Creswell, J. W. (2014). Qualitative inquiry and research design: Choosing among five approaches. Sage Publication.

Darmawan, F. W., Chumaidiyah, E., \& Sagita, B. H. (2018). Analisis kelayakan revitalisasi pasar tradisional banjaran Kabupaten Bandung menggunakan container bekas dengan indikator Benefit Cost Ratio, Payback Period, dan Net Present Value. E-Proceeding of Engineering, 2489-2994.
Denhardt, J. v., \& Denhardt, R. B. (2015). The New Public Service Revisited. Public Administration Review. https://doi.org/10.1111/puar.12347

Denzin, N. (1978). The research act: A theoretical introduction to sociological methods (2nd ed.). McGraw-Hill.

Dunn, W. (2003). Analisis Kebijakan Publik. PT. Prasetia Widia Pratama.

Dunn, W. N. (2000). Public policy analysis : an introduction. Routledge (Taylor \& Francis Group).

Haedar. (2015). Evaluasi kebijakan program nasional pemberdayaan masyarakat mandiri perdesaan di kelurahan kabonga besar kecamatan benawa kabupaten donggala. $E$ Journal Katalogis, 3(5), 39-47.

Irvin, R. A., \& Stansbury, J. (2004). Citizen Participation in Decision Making: Is It Worth the Effort? Public Administration Review, 64(1), 55-65.

Khotimah, C. K., Rahayu, M. J., \& Putri, R. A. (2017). Efektivitas revitalisasi pasar regional di Kabupaten Klaten. Jurnal Pengembangan Kota, 5(1), 28-36. https://doi.org/10.14710/jpk.5.1.28-36

Moleong, L. J. (2012). Metodelogi penelitian kualitatif. Remaja Rosdakarya.

Muchdoro, A. M. (1997). Teori dan Perilaku Organisasi. Deepublish.

Muhiddin, A. (2017). Evaluasi kebijakan publik (Studi kesiapan desa menerima dana desa di kabupaten gowa).

Mulyadi. (1998). Total Quality management. Aditya Media.

Nilda, Adnyana, I. W. S., \& Merit, I. N. (2014). Analisis perubahan penggunaan lahan dan dampaknya terhadap hasil air di das cisadane hulu. Ecotrophic, 9(1), 35-45.

Pangestu, M. (2004). Pasar tradisional yang modern dalam rangka peningkatan daya saing pasar tradisional. In Biro Penerbit Planologi Undip (Vol. 10, Issue 2). 
www.usdrpindonesia.org/files/downlo adCategory/72

Porter, M. E. (2008). Competitive strategy: Techniques for analyzing undustries and competitors. Simon and Schuster.

Prastyawan, A., \& Isbandono, P. (2018). The role of local governments in traditional market revitalization. Journal of Physics: Conference Series, 953(1).

Reily, M. (2019). Kejar target revitalisasi, Pemerintah turunkan klasifikasi pasar. Katadata. https://katadata.co.id/berita/2019/02/2 0/kejar-target-revitalisasi-pemerintahturunkan-klasifikasi-pasar

Rosmayanti. (2018). Revitalisasi pasar rakyat dinilai berhasil, Sejumlah daerah belajar ke denpasar. Warta Ekonomi : Perspektif Baru Bisnis \& Ekonomi.

https://www.wartaekonomi.co.id/read 198308/revitalisasi-pasar-rakyatdinilai-berhasil-sejumlah-daerahbelajar-ke-denpasar.html

Sitorus, T. (2013). Analisis daya saing sektor pariwisata kota medan. Repository Universitas Sumatra Utara.

http://repository.usu.ac.id/handle/123 456789/38206

Stutiari, N. P. E., \& Arka, Sudarsana. (2019). Dampak revitalisasi pasar tradisional terhadap pendapatan pedagang dan tata kelola pasar di kabupaten Badung. E-Jurnal EP Unud, 8(1), 148-178.

Syamsuddin. (2017). Evaluasi kebijakan ketertiban umum di Kota Palu (Studi kasus perda nomor 21 tahun 1998 Tentang larangan pembuatan protistusi dan praktik tuna susila dala wilayah kotamadya palu). E Jurnal Katalogis, 5(12), 185-191.

Tresiana, N., \& Duadji. N. (2020). Implementasi dan evaluasi kebijakan publik. Ghara Ilmu.

Winarno, B. (2002). Teori dan proses kebijakan publik. Media Pressindo.

Yudiatmaja, W. E. (2016). Implementasi dan evaluasi kebijakan publik. UMRAH Press.

Yudithia, Y., \& Mahadiansar, M. (2019). Perilaku organisasi positif dalam kinerja; Sebuah konsep dan teori. UMRAH Press.

Zed, M. (2014). Metode penelitian kepustakaan (3rd ed.). Yayasan Obor Indonesia.

\section{Websites}

https://republika.co.id/berita/q3x2yy384/pu pr-targetkan-revitalisasi-4-pasar-iniselesai-2020

https://suryakepri.com/2020/01/30/telanrp27-miliar-revitalisasi-pasarpotong-lembu-selesai-syahrulsemoga-menambah-pendapatandaerah/2/

https://wartarakyat.co.id/2020/01/30/walik ota-dan-wakil-walikotatanjungpinang-resmikan-pasarpotong-lembu/

https://sijoritoday.com/2019/03/12/reseske-bumd-dewan-bahas-perbaikanpasar-potong-lembu/

https://transkepri.com/news/detail/3995/pr oyek-revitalisasi-akau-potonglembu-senilai-rp22-m-jadi-temuanbpk

https://zonakepri.com/tuntas-revitalisasipasar-potong-lembu-kembalidifungsikan/ 